\title{
Wpływ energii liniowej na skłonność powstawania pęknięć gorących w procesie spawania stali S355J2WP metodą 135
}

\author{
Linear Energy Impact on Formation of Hot Cracks \\ in the Welding Process of Steel S355J2WP by 135 Method
}

\section{Streszczenie}

Wytrzymałość i trwałość konstrukcji stalowych podczas eksploatacji zależy w dużej mierze od jakości wykonania złącz. Niedopuszczalne niezgodności i wady złączy spawanych mogą być przyczyną awarii. W artykule przedstawiono wybrane aspekty wpływu energii liniowej spawania metodą 135 stali trudnordzewiejącej S355J2WP na skłonność powstawania pęknięć gorących. Celem wykonanych prób spawania było określenie parametrów stanu optymalnego z uwzględnieniem zredukowania do minimum dostarczonej energii cieplnej oraz z wykorzystaniem nowoczesnych metod planowania eksperymentu i statystycznego opracowania wyników, pozwalających na wyznaczenie modelu matematycznego obiektu badań w postaci funkcji regresji. W artykule zwrócono też uwagę na wątpliwości dotyczące prawidłowego sposobu definiowania energii liniowej spawania.

Słowa kluczowe: spawalność, parametry i energia liniowa spawania, pęknięcia gorące

\begin{abstract}
The strength and durability of steel constructions during their exploitation depends on the quality of the joints. Unacceptable discrepancies and defects of welding joints may cause failures. This article presents selected aspects of the linear energy impact on the tendency for formation of hot cracks in the process of welding rust resistant steelS355J2WP by 135 method. The purpose of the welding attempts that have been made was to define the optimum state parameters, while reducing thermal energy supply to a minimum, using modern methods of experiment planning and statistical treatment of results, which allowed for developing a methematical research object model in the form of a regression function. The article also highlights certain doubts concerning the appropriate way of defining the linear energy of welding.
\end{abstract}

Keywords: weldability, parameters and linear energy of welding, hot cracks

\section{Wstęp}

Stale trudnordzewiejące łączą w sobie dwie cechy nowoczesnych stali konstrukcyjnych: podwyższoną odporność na warunki atmosferyczne i podwyższoną wytrzymałość. W składzie mają niską zawartość pierwiastków stopowych: chromu, niklu, miedzi i fosforu. Pierwiastki te pod wpływem warunków atmosferycznych hamują postęp korozji. Stale te w warunkach suchy - mokry, pokrywają się cienką i odporną na korozję powłoką tlenków - patyną, ograniczającą jej postęp w głąb materiału. Szybkość korozji jest w nich 23 krotnie mniejsza niż stali konstrukcyjnej o podobnej wytrzymałości. Stale te mogą być również pokryte powłokami ochronnymi. Po pokryciu powłoką ochronną tworzenie się patyny zostaje zatrzymane, jednak postęp korozji w przypadku uszkodzenia powłoki ochronnej jest znacznie mniejszy niż w stalach zwykłych.

Podstawowym sposobem łączenia elementów konstrukcyjnych stalowych jest spawanie łukowe, a najpopularniejszą jego odmianą jest spawanie metodą 135 (spawanie łukowe elektrodą topliwą $w$ atmosferze gazu aktywnego chemicznie). Metoda ta stosowana jest niemal we wszystkich gałęziach przemysłu. Do spawania stali trudnordzewiejących należy zastosować materiały spawalnicze o odporności korozyjnej zbliżonej do materiału rodzimego, zawierające w składzie: miedź, chrom i nikiel [1].

Podstawowymi parametrami spawania metodą 135 są: natężenie prądu spawania I, napięcie łuku U

Mgr inż. Stanisław Pałubicki, mgr inż. Stanisław Karpiński - Politechnika Koszalińska. 
i prędkość spawania v. Między tymi parametrami istnieją bezpośrednie związki mające wpływ na jakość wykonywanych połączeń spawanych. Wielkością łączącą ze sobą, wspomniane wcześniej, podstawowe parametry spawania łukowego jest energia liniowa spawania Q. Jest ona uznawana za podstawowy parametr doboru warunków spawania oraz jako wielkość będącą bazą dla innych wskaźników obliczanych i stosowanych w procesach spawania.

Głównym czynnikiem decydującym o przydatności stali do spawania i wyborze technologii spawania jest jej skład chemiczny. Skład chemiczny stali S355J2WP przedstawiono $\mathrm{w}$ tablicy I, a własności mechaniczne w tablicy II.

Tablica II. Własności mechaniczne stali S355J2WP dla blachy o grubości nominalnej $10 \mathrm{~mm}$ [2]

Table II. Mechanical qualities of steel S355J2WP for a sheet of 10 $\mathrm{mm}$ nominal thickness [2]

\begin{tabular}{|c|c|}
\hline Nazwa & Wartość \\
\hline Granica plastyczności $\mathrm{R}_{\mathrm{eH}}$ & $\geq 355$ \\
\hline Wytrzymałość na rozciąganie $\mathrm{R}_{\mathrm{m}}, \mathrm{MPa}$ & $470-630$ \\
\hline Minimalne wydłużenie próbki $\mathrm{A}, \%$ & 20 \\
\hline
\end{tabular}

Wskaźnikiem spawalności rozpatrywanej stali jest tzw. równoważnik chemiczny (ekwiwalent węgla) Cekw wyrażony równaniem [3]:

$\mathrm{U}_{\text {ekw }}=\mathrm{C}+2 \mathrm{~s}+\frac{\mathrm{P}}{3}+\frac{\mathrm{Si}-0,4}{10}+\frac{\mathrm{Mn}-0,8}{12}+\frac{\mathrm{Ni}}{12}+\frac{\mathrm{Cu}}{15}+\frac{\mathrm{Cr}-0,8}{15}$

gdzie: C, S, P, Si, Mn, Ni, Cu, Cr - procentowa zawartość pierwiastków stopowych w stali.

Równoważnik chemiczny, obliczony według zależności (1), dla stali S355J2WP wynosi:

$$
\begin{aligned}
U_{\text {ekw }} & =0,12+2 \cdot 0,03+\frac{0,15}{3}+\frac{0,75-0,4}{10}+\frac{1-0,8}{12}+\frac{0,65}{12}+ \\
& +\frac{0,55}{15}+\frac{1,25-0,8}{15}=0,402
\end{aligned}
$$

Pęknięcia gorące są jednymi z najczęściej występujących niezgodności, powstających $\mathrm{w}$ procesie spawania, które mogą zdyskwalifikować wykonane złącze. Szczególne znaczenie ze względu na bezpieczeństwo eksploatacji konstrukcji spawanych mają pęknięcia krystalizacyjne w spoinie.
Powstawanie pęknięć gorących może być uwarunkowane $[3,4]$ :

- składem chemicznym metalu spoiny,

- warunkami i charakterem procesu krystalizacji,

- stopniem rozwoju niejednorodności wewnątrzkrystalicznej,

- wartością energii liniowej spawania,

- typem złącza oraz współczynnikiem kształtu spoiny,

- konstrukcją i sztywnością połączenia spawanego.

Wartości $\mathrm{C}_{\mathrm{ekw}}$ stosowane jako kryterium oceny skłonności do pęknięć gorących dla stali trudnordzewiejących wynoszą odpowiednio [3]:

- $\mathrm{C}_{\text {ekw }}>0,45$ - stal skłonna,

- $\mathrm{C}_{\text {ekw }}<0,15$ - stal odporna,

- 0,15< $\mathrm{C}_{\text {ekw }}<0,45$ - stal częściowo skłonna.

Stal S355J2WP przy wartości $C_{\text {ekw }}=0,402$ można zaliczyć do grupy stali częściowo skłonnych do powstawania pęknięć gorących, czyli niemających nieograniczonej przydatności do spawania. W związku z tym, podczas opracowywania technologii spawania, należy wziąć pod uwagą warunki wykonania i eksploatacji złącza oraz wymiary i kształt konstrukcji.

\section{Energia liniowa spawania}

Energia liniowa jest to ilość ciepła przypadająca na jednostkę długości spoiny l, według PN EN 1011-1: 2009 jest to ilość wprowadzonego ciepła Q. Oblicza się ją z następującej zależności [5]:

$$
\mathrm{Q}=\mathrm{k} \cdot \frac{\mathrm{U} \cdot \mathrm{I}}{\mathrm{v}} \cdot 10^{-3} \mathrm{~kJ} / \mathrm{mm}
$$

gdzie: k - współczynnik sprawności cieplnej (dla metody 135), $\mathrm{k}=0,8$ [6], $\mathrm{U}$ - napięcie łuku $\mathrm{W} \mathrm{V}, \mathrm{I}$ - natężenie prądu spawania $w A, v$ - prędkość spawania w $\mathrm{mm} / \mathrm{s}$.

Energii liniowej nie można mierzyć bezpośrednio. Została ona wyliczona na podstawie wzoru (2), w oparciu o zmierzone wartości: napięcia łuku, natężenia prądu spawania oraz prędkości spawania. Do obliczeń przyjęto wartości średnie wymienionych parametrów.

\section{Metodyka badań}

Podstawą statystycznych metod identyfikacji obiektów jest rozpatrywanie rzeczywistych obiektów jako

\begin{tabular}{|c|c|c|c|c|c|c|c|c|c|c|c|c|c|}
\hline \multirow{2}{*}{\multicolumn{2}{|c|}{$\begin{array}{c}\begin{array}{c}\text { Znak } \\
\text { stali }\end{array} \\
\text { S355J2WP }\end{array}$}} & \multirow{2}{*}{\multicolumn{2}{|c|}{$\begin{array}{c}\text { Metoda } \\
\text { odtleniania }\end{array}$}} & \multicolumn{2}{|c|}{$\begin{array}{c}\text { C } \\
\text { (węgiel) }\end{array}$} & \multicolumn{2}{|c|}{$\begin{array}{c}\text { Mn } \\
\text { (mangan) }\end{array}$} & \multicolumn{2}{|c|}{$\begin{array}{c}\text { Si } \\
\text { (krzem) }\end{array}$} & \multicolumn{2}{|c|}{$\begin{array}{c}P \\
\text { (fosfor) }\end{array}$} & \multicolumn{2}{|c|}{$\begin{array}{c}\mathrm{S} \\
\text { (siarka) }\end{array}$} \\
\hline & & & & 0 & 0,12 & 0 & 1 & 0 & 0,75 & 0,06 & 0,15 & 0 & 0,03 \\
\hline \multicolumn{2}{|c|}{$\begin{array}{c}\mathrm{Cr} \\
\text { (chrom) }\end{array}$} & \multicolumn{2}{|c|}{$\begin{array}{c}\mathrm{Ni} \\
\text { (nikiel) }\end{array}$} & \multicolumn{2}{|c|}{$\begin{array}{c}\mathrm{Cu} \\
\text { (miedź) }\end{array}$} & \multicolumn{2}{|c|}{$\begin{array}{c}\text { Al } \\
\text { (aluminium } \\
\text { całkowite) }\end{array}$} & \multicolumn{2}{|c|}{$\begin{array}{c}\mathrm{Nb} \\
\text { (niob) }\end{array}$} & \multicolumn{2}{|c|}{$\begin{array}{c}\text { V } \\
\text { (wanad) }\end{array}$} & \multicolumn{2}{|c|}{$\begin{array}{c}\mathrm{Ti} \\
\text { (tytan) }\end{array}$} \\
\hline 0,3 & 1,25 & 0 & 0,65 & 0,25 & 0,55 & 0,02 & 0 & 0,015 & 0,06 & 0,02 & 0,12 & 0,02 & 0,1 \\
\hline
\end{tabular}

Tablica I. Własności mechaniczne stali S355J2WP dla blachy o grubości nominalnej $10 \mathrm{~mm}$ [2]

Table I. Mechanical qualities of steel S355J2WP for a sheet of $10 \mathrm{~mm}$ nominal thickness [2] 
procesów losowych, statystycznych. Wykorzystując zasadę „czarnej skrzynki”, tj. braku pełnej znajomości mechanizmów obiektu, poszukuje się związków pomiędzy zmiennymi wyjściowymi a zmiennymi wejściowymi (znanymi i pozwalającymi na sterowanie).

Eksperyment zaplanowano przy wykorzystaniu programu Experiment Planner 1.0.1. Jest to program komputerowy służący do planowania eksperymentów rozpoznawczych (identyfikacyjnych) i właściwych [7,8]. Dokonano określenia istotności wpływu czynników wejściowych i ich parametrów dla badań właściwych wpływu energii liniowej spawania stali trudnordzewiejącej S355J2WP metodą 135 na skłonność powstawania pęknięć gorących. Czynniki wejściowe (ang. input factors) to czynniki wpływające istotnie na czynnik wynikowy, jak również czynniki nieistotne lub niepoddawane badaniu $w$ danym eksperymencie, określające jednak warunki, w jakich ma być on prowadzony. Zostały one zestawione w tablicy III (czynniki badane: poz. $3,4,6)$.

Tablica III. Czynniki wejściowe i ich parametry dla badań właściwych wpływu energii liniowej spawania stali trudnordzewiejącej S355J2WP na skłonność powstawania pęknięć gorących dla metody 135

Table III. Input factors and their parameters for the study of linear energy impact on the tendency for formation of hot cracks in the process of welding rust resistant steel S355J2WP by method 135

\begin{tabular}{|c|c|}
\hline Czynniki wejściowe & $\begin{array}{c}\text { Parametry czynników } \\
\text { wejściowych } \\
\text { dla metody spawania } 135\end{array}$ \\
\hline $\begin{array}{c}\text { Symbol spoiny/pozycja } \\
\text { spawania }\end{array}$ & FW/PB \\
\hline Średnica elektordy, mm & 1,2 \\
\hline Natężenie prądu, A & 190300 \\
\hline Biegunowość & $\mathrm{DC}(+)$ \\
\hline $\begin{array}{c}\text { Prędkość spawania, } \\
\mathrm{mm} / \mathrm{s}\end{array}$ & 67 \\
\hline $\begin{array}{l}\text { Materiał dodatkowy } \\
\text { (spoiwo) }\end{array}$ & $\begin{array}{c}\text { Multimet IMT } 2 \mathrm{wg} \text {. EN ISO } \\
1431 \mathrm{~A}\end{array}$ \\
\hline Gaz ochronny & $\begin{array}{c}\text { M21 wg. PN-EN ISO } 14175 \\
\left(80 \% \mathrm{Ar}+20 \% \mathrm{CO}_{2}\right)\end{array}$ \\
\hline $\begin{array}{c}\text { Natężenie przepływu } \\
\text { gazu ochronnego, 1/min }\end{array}$ & 1518 \\
\hline $\begin{array}{c}\text { Rodzaj przygotowania } \\
\text { i czyszczenia } \\
\text { przed spawaniem }\end{array}$ & $\begin{array}{c}\text { Usunięto warstwę patyny, } \\
\text { odsłaniając czystą stal na } \\
\text { powierzchni o szerokości } \\
1020 \text { mm wzdłuż } \\
\text { spawanego złącza }\end{array}$ \\
\hline Podgrzewanie wstępne, ${ }^{\circ} \mathrm{C}$ & 100 \\
\hline $\begin{array}{l}\text { Max. temperatura } \\
\text { międzyściegowa, }{ }^{\circ} \mathrm{C}\end{array}$ & 190 \\
\hline
\end{tabular}

Plan badań właściwych opracowano jako plan trójpoziomowy (3LExp - 3 levels experiment). Umożliwia on identyfikację obiektów nieliniowych opisywanych np. funkcją kwadratową. Plan ten stosowany jest do badania obiektów o 13 czynników zmiennych.
Liczba doświadczeń w tym planie wynosi $3^{\text {s }}$ (gdzie: s - liczba czynników zmiennych) $[7,8]$. Zakłada on badanie czynników na następujących poziomach:

- poziom górny (maksymalny),

- poziom centralny (średni),

- poziom dolny (minimalny).

W kolejnych oknach programu Experiment Planner 1.0.1 zdefiniowano eksperyment, określono liczbę pomiarów i poziom istotności a (rys. 1) oraz zdefiniowano czynniki wejściowe (rys. 2).

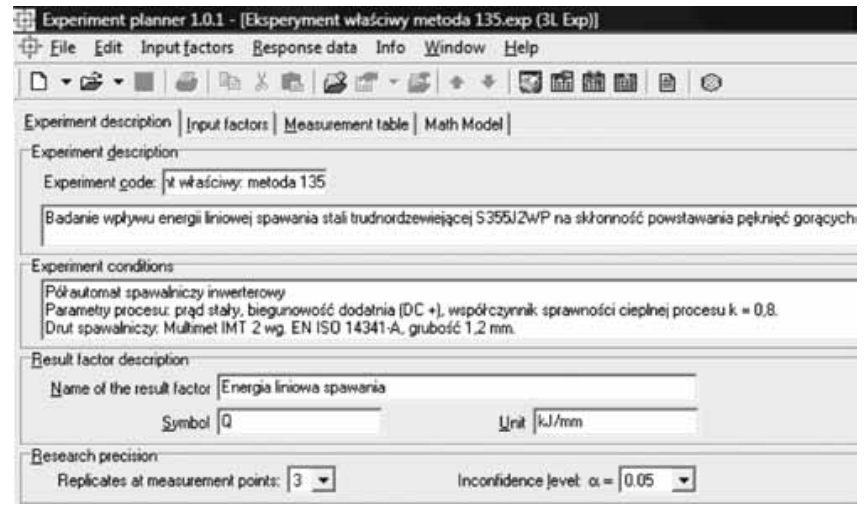

Rys. 1. Widok okna definicji eksperymentu właściwego dla metody $135 \mathrm{z}$ wykorzystaniem programu Experiment Planner 1.0.1

Fig. 1. View of the window of the specific experiment's definition for method 135 with the use of Experiment Planner 1.0.1 application

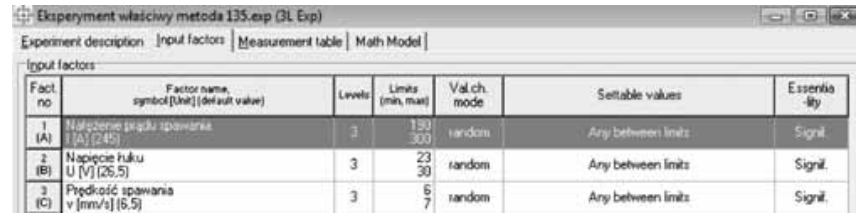

Rys. 2. Widok okna definicji czynników wejściowych dla eksperymentu właściwego dla metody $135 \mathrm{z}$ wykorzystaniem programu Experiment Planner 1.0.1

Fig. 2. View of the window of the definition of input factors for the specific experiment for method 135 with the use of Experiment Planner 1.0.1 application

Próbki badawcze wykonano jako złącze teowe ze spoiną pachwinową, ze względu na większą skłonność spoin pachwinowych do pęknięć krystalizacyjnych [3,9]. Przy takim samym współczynniku kształtu, ryzyko pękania spoiny pachwinowej jest o około $25 \%$ większe niż spoin doczołowych $[3,10]$.

Pomiaru energii liniowej dokonano metodą pośrednią, w oparciu o zmierzone wartości: napięcia łuku, natężenia prądu spawania oraz prędkości spawania. Prędkość spawania przeliczono na czas spawania pojedynczego ściegu próbki (długość próbek wynosiła $200 \mathrm{~mm}$ ) i dokonywano pomiarów ww. czasu.

Stanowisko do badań wpływu energii liniowej spawania metodą 135 na skłonność powstawania pęknięć gorących wyposażono w półautomat spawalniczy z wydzielonym podajnikiem FIGEL 500. Stanowisko zasilano gazem osłonowym z centralnej instalacji, której przyłącza wyposażone są w zawory regulacyjne i rotametry. Próby spawania przeprowadzono z parametrami określonymi w opracowanym planie eksperymentu przy zastosowaniu jako materiału dodatkowego drutu elektrodowego Multimet IMT 20 średnicy 1,2 mm. 
Przed spawaniem próbki podgrzano do temperatury początkowej określonej w tablicy III. Temperatura ta została określona na podstawie empirycznej zależności Seferiana [3, 11]:

$$
T_{p}=350 \sqrt{C_{e}(1+0,005 g)-0,25^{\circ} \mathrm{C}}
$$

gdzie: g - grubość blachy w mm, Ce - chemiczny równoważnik węgla.

Próbki spawano w trybie ręcznej regulacji parametrów spawania. Zadane parametry wprowadzano poprzez dotykową klawiaturę znajdującą się na podajniku urządzenia.

\section{Wyniki badań}

Do wykrycia niezgodności spawalniczych występujących w wykonanych złączach badawczych wykorzystano trzy metody badań:

- badania nieniszczące (do niezgodności zewnętrznych):

- badania wizualne(VT) wg. PN-EN ISO 17637:2011,

- badania magnetyczno-proszkowe (MT) wg. PNEN ISO 17638:2010,

- badania niszczące (do niezgodności wewnętrznych), wg. PN-EN ISO 17641-1: 2005: przecięto mechanicznie pas próbki między spoinami wzdłuż osi podłużnej i rozłamano próbki, przełom spoiny poddano oględzinom w celu wykrycia pęknięć w grani. W wyniku przeprowadzonej oceny jakości wykonania próbek badawczych nie stwierdzono występowania pęknięć gorących. Ze względu na jakość spoin próbki podzielono na trzy grupy, jako kryterium wykorzystano wartość energii liniowej spawania:

- grupa I - mała wartość energii liniowej spawania: $Q<0,7 \mathrm{w} \mathrm{kJ} / \mathrm{mm}$, jest przyczyną rozprysku, braku przetopu, przyklejeń i nieregularnego kształtu spoiny, spoina jest wąska i nieregularna a przetopienie ma kształt owalny (przelot grubokroplowy), rysunek 3,
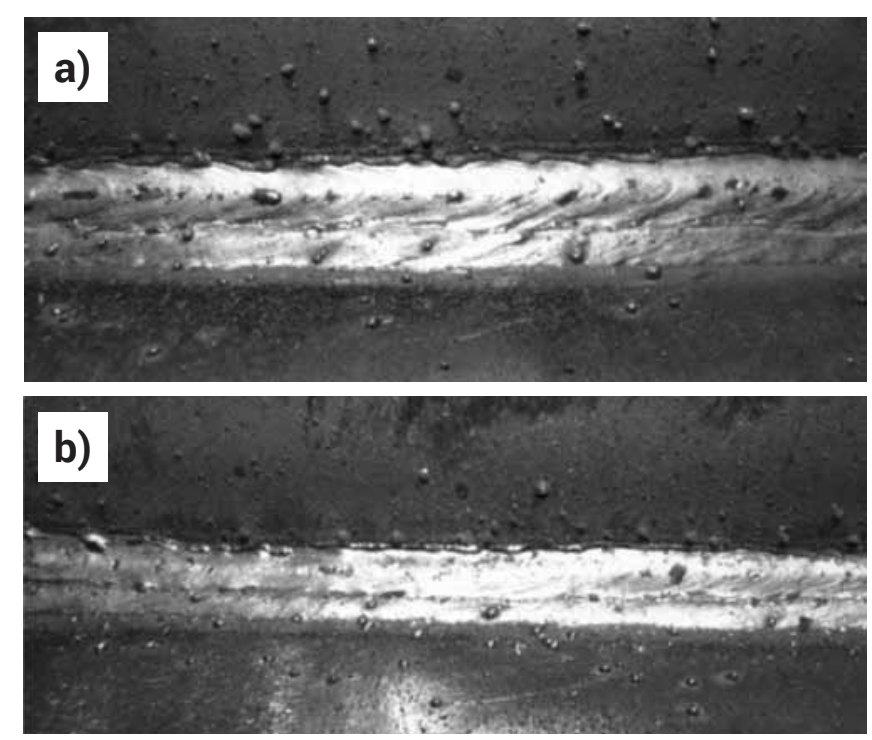

Rys. 3. Widok spoiny $\mathrm{FW}$ spawanej metodą 135 o parametrach: a) $I=190 \mathrm{~A}, U=26,5 \mathrm{~V}, v=7 \mathrm{~mm} / \mathrm{s}, Q=0,576 \mathrm{~kJ} / \mathrm{mm}$, b) $I=190 \mathrm{~A}$, $U=30 \mathrm{~V}, v=7 \mathrm{~mm} / \mathrm{s}, Q=0,654 \mathrm{~kJ} / \mathrm{mm}$

Fig. 3. View of FW weld obtained by 135 method with parameters: a) $I=190 \mathrm{~A}, U=26.5 \mathrm{~V}, v=7 \mathrm{~mm} / \mathrm{s}, Q=0.576[\mathrm{~kJ} / \mathrm{mm}]$, b) $I=190 \mathrm{~A}$, $U=30 \mathrm{~V}, v=7 \mathrm{~mm} / \mathrm{s}, Q=0.654 \mathrm{~kJ} / \mathrm{mm}$
- grupa II - średnia wartość energii liniowej spawania: $0,7 \leq Q \leq 1 \mathrm{w} \mathrm{kJ} / \mathrm{mm}$, wtopienie jest szerokie przy licu, stopniowo zwęża się wraz ze wzrostem głębokości (kształt grzybka) rysunek 4, złącza poprawne,
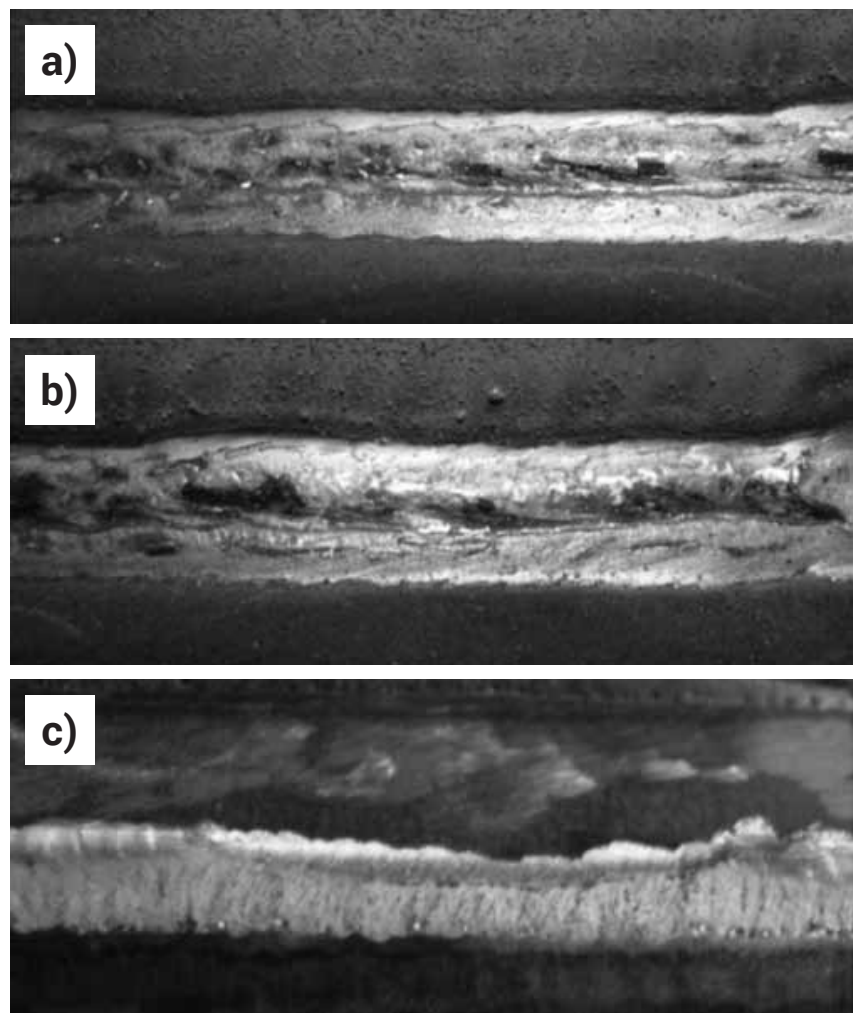

Rys. 4. Widok spoiny $\mathrm{FW}$ spawanej metodą 135 o parametrach: a) $I=300 \mathrm{~A}, U=23 \mathrm{~V}, \mathrm{v}=6,5 \mathrm{~mm} / \mathrm{s}, Q=0,85 \mathrm{~kJ} / \mathrm{mm}, \mathrm{b}) I=245 \mathrm{~A}$, $U=30 \mathrm{~V}, \mathrm{v}=7 \mathrm{~mm} / \mathrm{s}, Q=0,839 \mathrm{~kJ} / \mathrm{mm}, \mathrm{c}$ ) przełom próbki b

Fig. 4. View of FW weld obtained by 135 method with parameters: a) $I=300 \mathrm{~A}, U=23 \mathrm{~V}, v=6.5 \mathrm{~mm} / \mathrm{s}, Q=0.85 \mathrm{~kJ} / \mathrm{mm}, \mathrm{b}) I=245 \mathrm{~A}$, $U=30 \mathrm{~V}, v=7 \mathrm{~mm} / \mathrm{s}, Q=0.839 \mathrm{~kJ} / \mathrm{mm}, \mathrm{c}$ ) breakthrough sample $b$

- grupa III - górna wartość energii liniowej spawania: $Q>1 \mathrm{w} \mathrm{kJ} / \mathrm{mm}$, przetopienie ma miejscowe zagłębienie w wyniku oddziaływania skupionego strumienia metalu elektrodowego (przelot natryskowy), rozprysk i podtopienia, rysunek 5 .
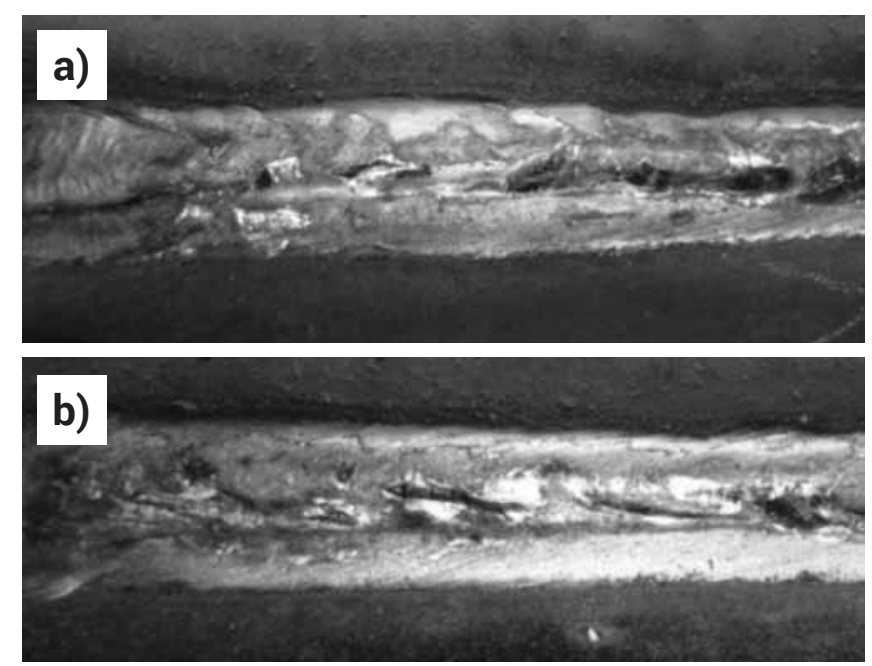

Rys. 5. Widok spoiny $\mathrm{FW}$ spawanej metodą 135 o parametrach: a) $I=300 \mathrm{~A}, U=30 \mathrm{~V}, v=6,5 \mathrm{~mm} / \mathrm{s}, Q=1,109 \mathrm{~kJ} / \mathrm{mm}$, b) $I=300 \mathrm{~A}$, $U=30 \mathrm{~V}, v=7 \mathrm{~mm} / \mathrm{s}, Q=1,032 \mathrm{~kJ} / \mathrm{mm}$

Fig. 5. View of FW weld obtained by 135 method with parameters: a) $I=300 \mathrm{~A}, U=30 \mathrm{~V}, v=6,5 \mathrm{~mm} / \mathrm{s}, Q=1.109 \mathrm{~kJ} / \mathrm{mm}, \mathrm{b}) I=300 \mathrm{~A}$, $U=30 \mathrm{~V}, v=7 \mathrm{~mm} / \mathrm{s}, Q=1.032 \mathrm{~kJ} / \mathrm{mm}$ 


\section{Wyznaczenie modelu matematycznego opisującego badany obiekt i sprawdzenie jego adekwatności}

Po zakończeniu spawania próbek badawczych i skompletowaniu wyników, wprowadzono je do dokumentu eksperymentu programu Experiment Planner 1.0.1.(rys. 6).

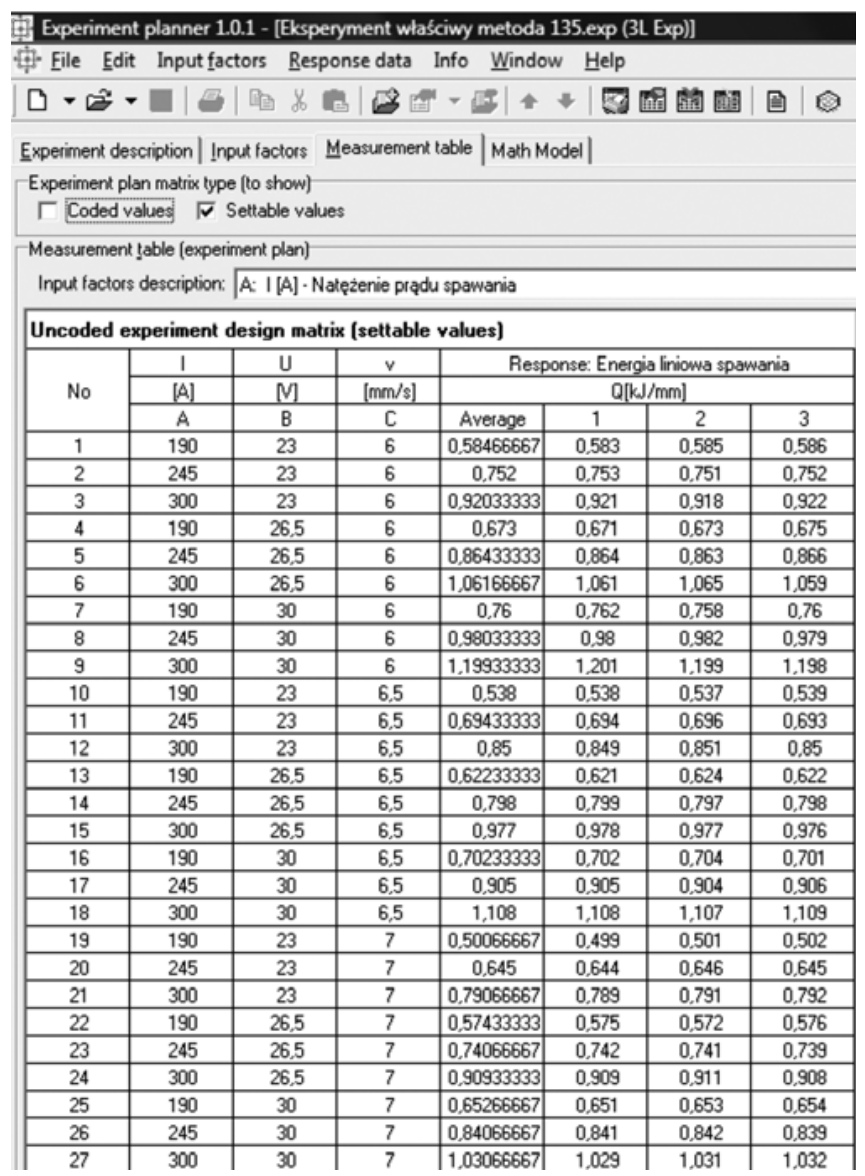

Rys. 6. Postać tabeli pomiarowej dla badań właściwych (plan trójpoziomowy - 3LExp) wpływu energii liniowej spawania stali trudnordzewiejącej S355J2WP na skłonność powstawania pęknięć gorących dla spoiny FW spawanej metodą 135

Fig. 6. Measurement table for the specific study (three-level plan - 3LExp) of linear energy impact on the tendency for formation of hot cracks in FW welds in the process of welding rust resistant steel S355J2WP by 135 method

W każdym doświadczeniu dokonano trzech pomiarów i przeprowadzono analizę wyników doświadczeń pod względem występowania błędów grubych. Z przeprowadzonej analizy wynika, że przy badaniu testem: B-Grubbsa, B4 i B6 żaden z wyników nie jest obciążony błędem grubym, można więc uznać, że dla analizowanych wyników różnice między powtórzeniami są nieistotne statystycznie - tzn. że zakłócenia w badanym procesie były na tyle niewielkie, że wszystkie wyniki mieszczą się w wyznaczonym zakresie.

Na podstawie wyników eksperymentu wyznaczono model matematyczny. Jako najbardziej odpowiednią funkcję regresji, opisującą proces spawania metodą 135, przedstawiającą zależność energii liniowej spawania od parametrów procesu, wybrano funkcję wykładniczą stopnia drugiego bez interakcji, która ma postać:
$\mathrm{Q}=\exp (-1,6387592+0,0081553237 * \mid+0,071599112 * \mathrm{U}-$ $-0,32084334 * \mathrm{v}-8,1847024 \mathrm{E}-\left.6 *\right|^{\wedge} 2-0,00063694597$ * $\left.\mathrm{U}^{\wedge} 2+0,012835959 * \mathrm{~V}^{\wedge} 2\right)$

Po obliczeniu współczynników funkcji regresji określono adekwatność modelu matematycznego opisującego badany proces.

Obliczony współczynnik korelacji wielowymiarowej $R$ dla wyznaczonego modelu matematycznego procesu spawania metodą 135 spoiny FW wynosi 0,9998 - świadczy to o dopasowaniu równania regresji do wyników eksperymentu.

Istotność współczynnika korelacji wielowymiarowej obliczono na podstawie porównania wartości funkcji testowej z wartością krytyczną (wartość testu F-Snedecora):

- wartość funkcji testowej: $F=1,4997$,

- wartość krytyczna funkcji dla założonego poziomu istotności : $F_{\text {kryt }}=2,12$.

W związku z tym, iż zachodzi nierówność: $F$ < Fkryt nie ma podstaw do odrzucenia hipotezy o istotności współczynnika korelacji wielowymiarowej i można stwierdzić, że model jest adekwatny do rezultatów eksperymentu dla założonego poziomu istotności $\alpha=0,05$.

Następnie określono istotność każdego z członów funkcji regresji. Istotność współczynników równania regresji obliczono przy pomocy testu t-Studenta. Z przeprowadzonych obliczeń wynika, iż wszystkie obliczone współczynniki równania są istotne i powinny znaleźć się w równaniu regresji.

Korzystając z funkcji Math Model and Experiment comparison, sprawdzono, jaka jest różnica wyników równania obiektu i równania modelu (rys. 7). Stwierdzono, że błąd jest mniejszy niż 0,1\% dla każdego doświadczenia oraz że wariancja dla całości doświadczeń jest mniejsza niż 0,01\%. Można zatem stwierdzić, że wyznaczony model matematyczny jest zgodny z zadaną funkcją $[7,8]$.

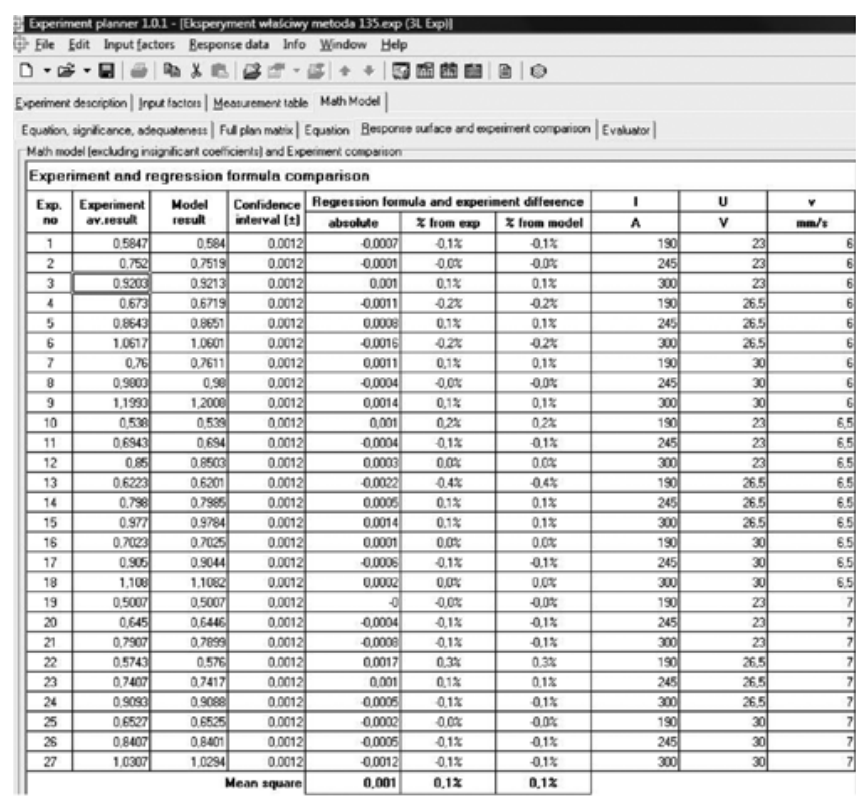

Rys. 7. Porównanie wyników eksperymentu i modelu matematycznego dla metody 135 z wykorzystaniem programu Experiment Planner 1.0.1 Fig. 7. Comparison of the experiment's results and the mathematical model for 135 method with the use of Experiment Planner 1.0.1 application 


\section{Wyznaczenie parametrów stanu optymalnego}

Po wyznaczeniu modelu matematycznego opisującego badany proces, sporządzono charakteryzujące go wykresy. Naniesiono na nie wyniki eksperymentu (tablica IV). Pozwalają one na szybką ocenę obiektu badań oraz wyznaczenie stanów optymalnych.

a)

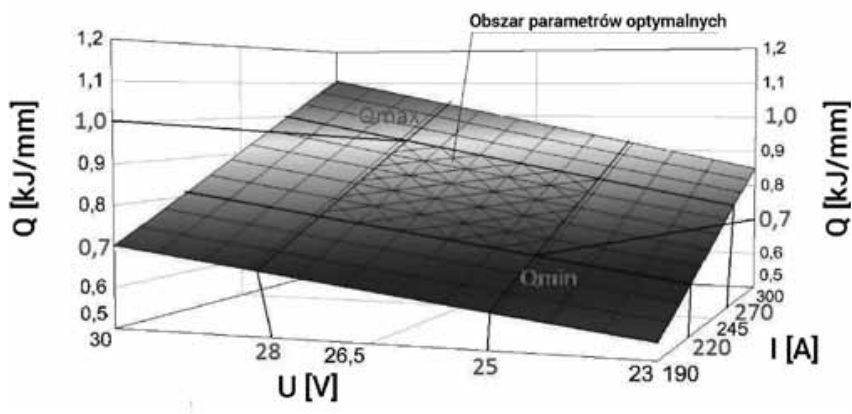

b)

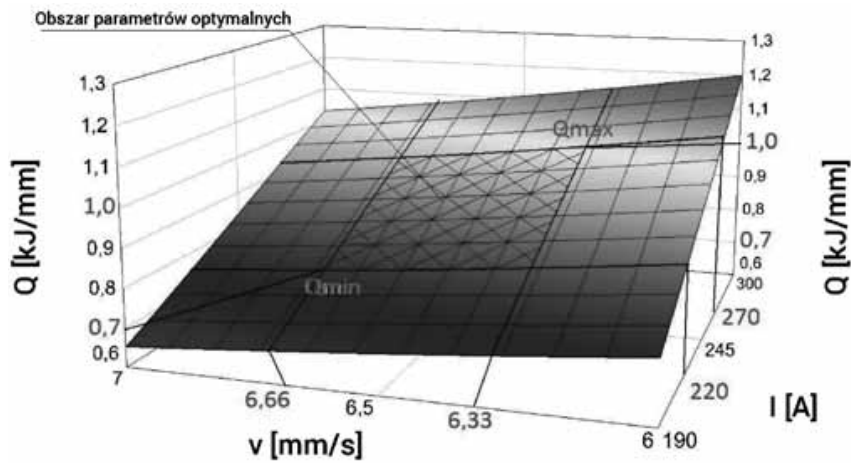

Rys. 8. Wykresy modelu matematycznego wartości energii liniowej $Q$ dla spoiny FW wykonanej metodą 135 , wyznaczone na podstawie przeprowadzonego eksperymentu z zaznaczonymi obszarami parametrów optymalnych: a) $U$ - napięcie łuku i I - natężenie prądu spawania, b) $I$ - natężenie prądu spawania i $v$ prędkość spawania Fig. 8. Charts of the mathematical model of the $Q$ linear energy value for FW welds obtained by 135 method, determined on the basis of the experiment conducted, with highlighted areas of optimum parameters: a) $U$ - arc tension and $I$ - voltage of welding, b) $I$ - voltage of welding and $v-$ speed of welding
Ponieważ w modelu występują trzy zmienne, wykonano wykresy trójwymiarowe (rys.8).

$\mathrm{Na}$ podstawie wyników opisanych powyżej prób badawczych opracowano instrukcję technologiczną spawania (ang. welding procedure specification - WPS) dla spoin pachwinowych złącza teowego wykonywanych metodą 135 dla stali trudnordzewiejącej S355J2WP o grubości 10 mm, zgodną z PN EN ISO 15609 1: 2007 (rys.9).

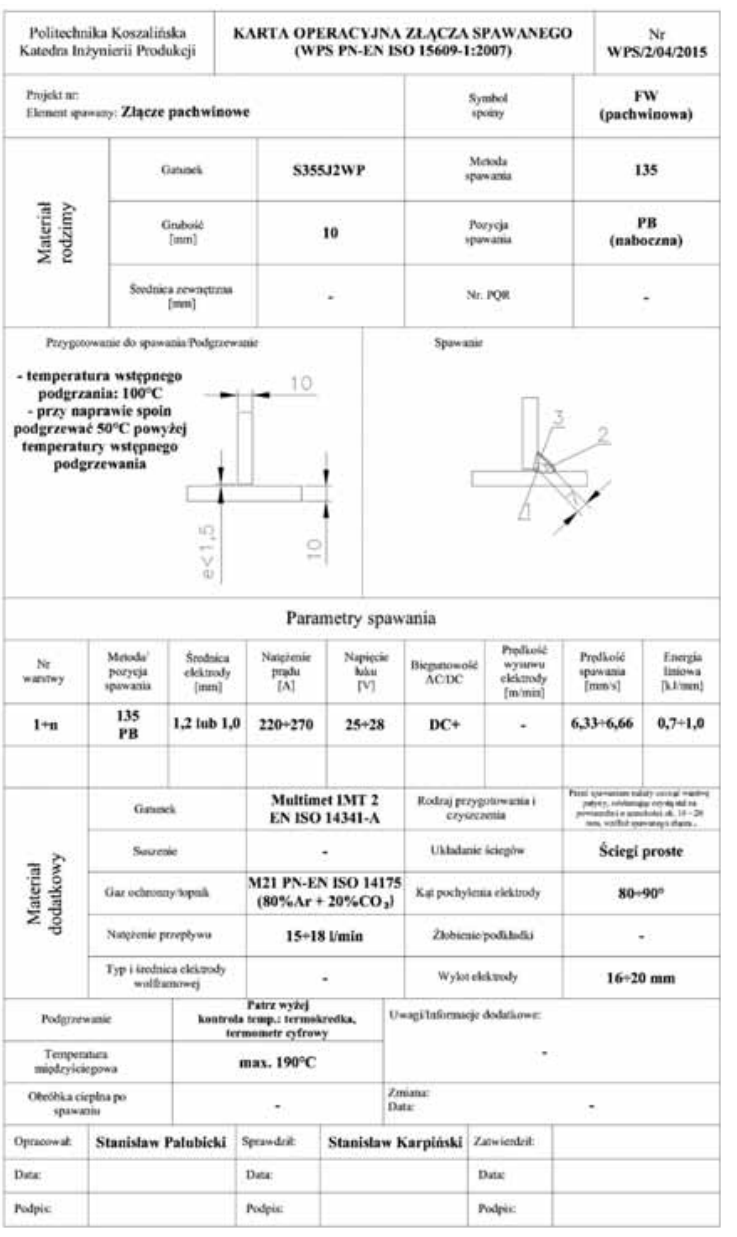

Rys. 9. Instrukcja technologiczna spawania dla spoiny pachwinowej złącza teowego zgodna z PNEN ISO 15609-1: 2007

Fig. 9. Welding procedure specification for FW weld obtained by 135 method compatible with PNEN ISO 15609-1: 2007

Tablica IV. Zestawienie wyników prób badawczych spawania spoin FW metodą 135 dla stali S355J2WP

Table IV. Compilation of the results of experimental attempts to FW welds obtained by 135 method for steel S355J2WP

\begin{tabular}{|c|c|c|c|c|c|c|c|c|c|c|c|c|}
\hline \multirow{2}{*}{ L.p. } & \multicolumn{3}{|c|}{$\begin{array}{c}\text { Energia liniowa spawania } Q \text {, } \\
\mathrm{kJ} / \mathrm{mm}\end{array}$} & \multirow{2}{*}{ L.p. } & \multicolumn{3}{|c|}{$\begin{array}{c}\text { Energia liniowa spawania } Q \text {, } \\
\mathrm{kJ} / \mathrm{mm}\end{array}$} & \multirow{2}{*}{ L.p. } & \multicolumn{3}{|c|}{$\begin{array}{c}\text { Energia liniowa spawania } Q \text {, } \\
\mathrm{kJ} / \mathrm{mm}\end{array}$} & \multirow[t]{2}{*}{ Oznaczenia: } \\
\hline & I pomiar & II pomiar & III pomiar & & I pomiar & II pomiar & III pomiar & & I pomiar & II pomiar & III pomiar & \\
\hline 1 & 0,583 & 0,585 & 0,586 & 10 & 0,538 & 0,537 & 0,539 & 19 & 0,499 & 0,501 & 0,502 & $Q<0,7$ \\
\hline 2 & 0,753 & 0,751 & 0,752 & 11 & 0,694 & 0,696 & 0,693 & 20 & 0,644 & 0,646 & 0,645 & \\
\hline 3 & 0,921 & 0,918 & 0,922 & 12 & 0,849 & 0,851 & 0,85 & 21 & 0,789 & 0,791 & 0,792 & \\
\hline 4 & 0,671 & 0,673 & 0,675 & 13 & 0,621 & 0,624 & 0,622 & 22 & 0,575 & 0,572 & 0,576 & \\
\hline 5 & 0,864 & 0,863 & 0,866 & 14 & 0,799 & 0,797 & 0,798 & 23 & 0,742 & 0,741 & 0,739 & $0,7 \leq Q \leq$ \\
\hline 6 & 1,061 & 1,065 & 1,059 & 15 & 0,978 & 0,977 & 0,976 & 24 & 0,909 & 0,911 & 0,908 & \\
\hline 7 & 0,762 & 0,758 & 0,76 & 16 & 0,702 & 0,704 & 0,701 & 25 & 0,651 & 0,653 & 0,654 & \\
\hline 8 & 0,98 & 0,982 & 0,979 & 17 & 0,905 & 0,906 & 0,906 & 26 & 0,841 & 0,842 & 0,839 & \\
\hline 9 & 1,201 & 1,199 & 1,198 & 18 & 1,108 & 1,107 & 1,109 & 27 & 1,029 & 1,031 & 1,032 & $Q>1$ \\
\hline
\end{tabular}




\section{Podsumowanie i wnioski}

W wyniku przeprowadzonej oceny jakości wykonania próbek badawczych nie stwierdzono występowania pęknięć gorących. Utrzymywanie energii liniowej spawania, będącej wskaźnikiem ilości ciepła wprowadzanego na jednostkę długości spoiny na określonym poziomie, prowadzi do właściwych efektów spawalniczych i metalurgicznych, czyli uzyskania poprawnego złącza spawanego.

W trakcie badań zaobserwowano różnice występujące w: polach przetopienia, strefach wpływu ciepła i głębokościach wtopienia uzyskane przy teoretycznie identycznej energii liniowej. Wynika $z$ tego wniosek, że energia liniowa nie jest parametrem dostatecznie precyzyjnym, nie uwzględnia bowiem wielu czynników mających bezpośredni wpływ na procesy cieplne i przemiany strukturalne zachodzące podczas procesu spawania (np. biegunowości i przebiegu prądu, współczynnika mocy łuku, rodzaju gazu osłonowego, średnicy elektrody i inne). Czynniki te, nieuwzględniane podczas doboru parametrów spawania, mogą doprowadzić do nieoczekiwanych problemów technologicznych, a w efekcie do niewłaściwego przebiegu procesu spawania.

Biorąc powyższe pod uwagą, w celu uzyskiwania powtarzalnych, ściśle określonych cech spoin, energia liniowa spawania powinna być traktowana jako parametr wymagający korekcji. Nowoczesne metody planowania eksperymentu oraz statystycznego opracowania wyników pozwalają na opracowanie modelu matematycznego obiektu badań w postaci funkcji regresji. Na jej podstawie pozwalają przewidywać wyniki prób technologicznych i wstępnie dobierać warunki spawania. Należy jednak sprawdzić je praktycznie przed zastosowaniem technologii w warunkach procesu produkcyjnego. Uzyskane wyniki pozwalają na zoptymalizowanie projektowania procesów technologicznych, a co za tym idzie skrócenie cyklu przygotowania produkcji i zmniejszenie kosztów z tym związanych, zwiększając konkurencyjność na rynku. Tego typu sposób doboru parametrów spawania, może znaleźć zastosowanie w zautomatyzowanych procesach spawalniczych.

Próby badawcze do pracy wykonano w Zamet Industry S.A. - Zakład Mostostal Chojnice.

\section{Literatura}

[1] [PN-EN 1090-2: 2009: Wykonanie konstrukcji stalowych i aluminiowych - Część 2: Wymagania techniczne dotyczące konstrukcji stalowych.

[2] PN-EN 10025-5: 2007: Wyroby walcowane na gorąco ze stali konstrukcyjnych - Część 5: Warunki techniczne dostawy stali konstrukcyjnych trudnordzewiejących.

[3] E. Tasak, A. Ziewiec: Spawalność materiałów konstrukcyjnych, tom I, Spawalność stali. Wydawnictwo JAK, Kraków 2009.

[4] E. Tasak, A. Ziewiec: Charakterystyka pęknięć w połączeniach spawanych i sposoby zapobiegania. Spajanie metali i tworzyw w praktyce, 2007, $\mathrm{nr} 2$, s. 10-15.

[5] K. Ferenc: Spawalnictwo. Wydawnictwa Naukowo - Techniczne, Warszawa 2007.
[6] M. Łomozik: Metaloznawstwo i spawalność metali. Instytut Spawalnictwa, Gliwice 1997.

[7] L. Kukiełka: Podstawy badań inżynierskich. Wydawnictwo Naukowe PWN, Warszawa 2002.

[8] S. Kukiełka: Experiment Planner 1.0 - komputerowy program planowania eksperymentów rozpoznawczych i właściwych oraz identyfikacji i analizy modelu matematycznego obiektu badań. Praca magisterska. Politechnika Koszalińska, Koszalin 2002.

[9] PN-EN ISO 17641-1: 2005: Badania niszczące spoin w metalach. Badania pękania na gorąco złączy spawanych - Metody spawania łukowego - Część 1: Postanowienia ogólne.

[10]E. Tasak: Metalurgia spawania. Wydawnictwo JAK, Kraków 2008. 